\title{
Quantitative microbial risk assessment for waterborne pathogens in a wastewater treatment plant and its receiving surface water body
}

\author{
Joshua Mbanga ${ }^{1,2^{*}}$ (D) Akebe Luther King Abia ${ }^{1}$, Daniel Gyamfi Amoako ${ }^{1}$ and Sabiha. Y. Essack ${ }^{1}$
}

\begin{abstract}
Background: Access to safe water for drinking and domestic activities remains a challenge in emerging economies like South Africa, forcing resource-limited communities to use microbiologically polluted river water for personal and household purposes, posing a public health risk. This study quantified bacterial contamination and the potential health hazards that wastewater treatment plant (WWTP) workers and communities may face after exposure to waterborne pathogenic bacteria in a WWTP and its associated surface water, respectively.

Results: Escherichia coli (Colilert ${ }^{\oplus}$-18/ Quanti-Tray ${ }^{\oplus}$ 2000) and enterococci (Enterolert ${ }^{\oplus /}$ Quanti-Tray ${ }^{\circledR}$ 2000) were quantified and definitively identified by real-time polymerase chain reaction targeting the uidA and tuf genes, respectively. An approximate beta-Poisson dose-response model was used to estimate the probability of infection (Pi) with pathogenic E. coli. Mean E. coli concentration ranged from 2.60E $+02 / 100 \mathrm{~mL}$ to $4.84 \mathrm{E}+06 / 100 \mathrm{~mL}$; enterococci ranged from $2.60 \mathrm{E}+02 / 100 \mathrm{~mL}$ to $3.19 \mathrm{E}+06 / 100 \mathrm{~mL}$ across all sampled sites. Of the $580 \mathrm{E}$. coli isolates obtained from this study, $89.1 \%$ were intestinal, and $7.6 \%$ were extraintestinal pathogenic E. coli. The 579 enterococci obtained were $50.4 \%$ E. faecalis (50.4\%), 31.4\% E. faecium, 3.5\%, E. casseliflavus and 0.7\% E. gallinarum. The community health risk stemming from the use of the water for recreational and domestic purposes revealed a greater health risk ( $\mathrm{Pi}$ ) from the ingestion of $1 \mathrm{~mL}$ of river water from upstream (range, 55.1-92.9\%) than downstream (range, 26.8-65.3\%) sites. The occupational risk of infection with pathogenic E. coli for workers resulting from a once-off unintentional consumption of $1 \mathrm{~mL}$ of water was $0 \%$ (effluent) and $23.8 \%$ (raw influent). Multiple weekly exposures of $1 \mathrm{~mL}$ over a year could result in a Pi of 1.2 and $100 \%$ for the effluent and influent, respectively.
\end{abstract}

Conclusion: Our findings reveal that there is a potentially high risk of infection for WWTP workers and communities that use river water upstream and downstream of the investigated WWTP.

Keywords: Quantitative microbial risk assessment, Wastewater treatment plants, Escherichia coli, Enterococcus

\footnotetext{
*Correspondence: joshmbanga@gmail.com; joshua.mbanga@nust.ac.zw

1 Antimicrobial Research Unit, College of Health Sciences, University of

Kwazulu-Natal, Private Bag X54001, Durban 4000, South Africa

${ }^{2}$ Department of Applied Biology and Biochemistry, National University of

Science and Technology, P.O Box AC 939 Ascot, Bulawayo 00263, Zimbabwe
}

C C The Author(s). 2020 Open Access This article is licensed under a Creative Commons Attribution 4.0 International License, which permits use, sharing, adaptation, distribution and reproduction in any medium or format, as long as you give appropriate credit to the original author(s) and the source, provide a link to the Creative Commons licence, and indicate if changes were made. The images or other third party material in this article are included in the article's Creative Commons licence, unless indicated otherwise in a credit line to the material. If material is not included in the article's Creative Commons licence and your intended use is not permitted by statutory regulation or exceeds the permitted use, you will need to obtain permission directly from the copyright holder. To view a copy of this licence, visit http://creativecommons.org/licenses/by/4.0/ The Creative Commons Public Domain Dedication waiver (http://creativecommons.org/publicdomain/zero/1.0/) applies to the data made available in this article, unless otherwise stated in a credit line to the data. 


\section{Background}

Water shortage remains among the most pressing challenges the world currently faces. Over 844 million people do not have access to safe drinking water, and approximately 159 million still drink unprocessed water from surface water sources, including streams and lakes [1]. Low- and middle- income countries (LMICs) and emerging economies like South Africa, with densely populated urban centers and informal housing, tend to have inappropriate wastewater management systems, and these are set to experience greater pressure as the urban population increases [2]. Such populations resort to nearby water bodies like rivers for human and household waste disposal, leading to extensive pollution of these resources.

Faecal contamination of water with pathogenic bacteria, viruses, and protozoa remains one of the main causes of waterborne diseases as these microbes can persist in polluted water for protracted periods and ultimately cause infections $[3,4]$. Fecal contamination of water is mainly assessed using fecal indicator bacteria such as Escherichia coli and enterococci [5]. Assessing water quality is crucial as it allows for investigations into the causes of pollution and averts likely waterborne diseases, by providing evidence on the risks of human exposure related to different water uses $[6,7]$.

Due to the possible health threats linked to the occurrence of microbial pollutants in water resources, wastewater treatment plants (WWTP) were created as central units to reduce the pollutant loads to acceptable limits before the discharge of the resultant effluent into receiving water bodies. The detection of pathogenic microbes in WWTP effluents is, therefore, a cause of concern, especially for those involved in public health and water administration [8]. People living and working near WWTPs in urban settings are frequently exposed to a broad range of microbial pathogens $[9,10]$.

Diarrhoeagenic strains of E. coli (DEC) are among the most notable pathogens that have been isolated from wastewater effluents and at sites downstream of WWTPs $[9,10]$. Pathogenic E. coli can either result in extraintestinal or intestinal infections. Extraintestinal pathogenic $E$. coli (ExPEC) includes uropathogenic E. coli (UPEC), avian pathogenic E. coli (APEC), and neonatal meningitis $E$. coli (NMEC) $[11,12]$. Intestinal pathogenic E. coli (InPEC) or DEC is categorized into six groups: entero-hemorrhagic (EHEC), entero-pathogenic (EPEC), entero-aggregative (EAEC), enterotoxigenic (ETEC), entero-invasive (EIEC), and diffusely adherent (DAEC) $[9,13]$.

South Africa's rural, peri-urban and informal settlements in urban areas house communities that remain heavily dependent on rivers and other water bodies for their everyday water requirements, some of which are polluted by treated and untreated WWTP discharges $[10,14]$. In KwaZulu-Natal province in South Africa the
uMsunduzi river is utilised for a variety of anthropogenic activities including domestic, industrial, agricultural and municipal activities [15]. The river flows through the provincial capital Pietermaritzburg (total population 900,113) and has a catchment size of $875 \mathrm{~km}^{2}$ and a tributary length of $115 \mathrm{~km}$ as it discharges into the uMgeni river [15]. Pietermaritzburg is characterized by numerous informal settlements next to surface water sources including the uMsunduzi river [14] which also receives runoff from a major WWTP in the city. Previous studies revealed that uMsunduzi River water (Pietermaritzburg) was contaminated with faecal matter and therefore unsafe for domestic, recreational and, agricultural purposes [14].

The likely exposure routes from polluted water sources include intentional and accidental ingestion, skin contact, and inhalation of droplets [16]. While the people in resource-poor communities may be exposed to all these routes, workers at WWTPs are more likely exposed to pathogens through inhalation of contaminated droplets [17]. This is particularly the case where proper personal protective equipment is not used or where personnel are not well trained. Exposure to bioaerosols generated in a WWTP can occur through numerous routes. Intake may be via the oral route from splashes, contaminated foodstuff, any hand-to-mouth contact, and contaminated personal protective equipment. Intake might also be via the respiratory system through inhalation of bioaerosols [17] or the skin such as by penetration through damaged or broken skin as a result of injuries. However, it is assumed that dermal contact and inhalation are less significant compared to exposure through ingestion [18].

For the river sites, probable exposure was considered to be through accidental or intentional ingestion of untreated river water by communities living upstream and downstream of the WWTP. Intentional ingestion might be due to direct consumption of the river water in places without access to a water supply. Accidental ingestion might occur due to the deliberate use of the polluted river water for household chores (washing clothes and cleaning dishes, among others) without treatment, and use of the river water for recreational activities like swimming or bathing $[6,19]$.

An in-depth understanding of the reservoirs of pathogens and their persistence in the environment is crucial in assessing the risks these microbes pose to the health of humans, animals, and the environment [20]. Quantitative microbial risk assessment (QMRA) is used to approximate the likelihood of health hazards resulting from human contact with pathogenic microbes in the environment $[7,16]$. QMRA has been used to determine the disease burden of pathogens $[2,6]$ and to assess the community health risks due to contact with polluted water $[2,6,10,21,22]$. QMRA is an essential tool as safe water for drinking, and domestic activities remains a 
challenge that is often exacerbated by inefficient and insufficient sanitation infrastructure [23]. It provides a vital basis for the implementation of measures to protect both community members and WWTP workers as there is scanty information on the potential risks linked to the regular use of and exposure to uMsunduzi River water. This study investigated probable direct exposure to pathogenic E. coli, which was assumed to occur mainly through ingestion and inhalation. This study aimed to (i) assess the microbial quality of treated and untreated wastewater from a major WWTP and its associated surface water in KwaZulu-Natal, South Africa and, (ii) estimate the potential human health hazards linked with exposure to waterborne pathogenic bacteria within the WWTP (workers' occupational exposure) and river water used by the communities.

\section{Results}

Mean concentrations of $E$. coli and Enterococcus spp.

All 60 water samples analyzed were positive for both E. coli and Enterococcus spp. The mean counts for both organisms are presented in Table 1. The arithmetic mean was used to compute the health risk due to pathogenic E. coli.
The mean monthly $E$. coli concentration ranged from $2.60 \mathrm{E}+02 / 100 \mathrm{~mL}$ (in the effluent) to $4.84 \mathrm{E}+06 / 100 \mathrm{~mL}$ (in the influent). For enterococci, mean monthly MPN ranged from $2.60 \mathrm{E}+02 / 100 \mathrm{~mL}$ (in the effluent) to $3.19 \mathrm{E}+06 / 100 \mathrm{~mL}$ (in the influent) over the 7 months. Consideration of both arithmetic and geometric averages by sampling location revealed that the concentration of enterococci was highest at the influent followed by the upstream site, downstream site and was lowest at the effluent site (Table 1). Notably, some results associated with the E. coli influent samples were beyond the limit of detection of the method used. In such instances, the averages were calculated using the limit of detection per $100 \mathrm{~mL}$.

For both organisms, the overall mean influent counts were significantly higher than the mean effluent counts $(p \leq 0.05)$. Similarly, the overall mean upstream counts were significantly higher than the mean downstream count $(p \leq 0.05)$.

\section{Molecular confirmation and characterization of E. coli and Enterococcus spp.}

In total, $580 \mathrm{E}$. coli isolates from the effluent $(n=130)$, influent $(n=150)$, downstream $(n=150)$, and upstream

Table 1 Average Enterococcus spp. and E. coli counts (MPN/100 mL) per month and site of collection

\begin{tabular}{|c|c|c|c|c|}
\hline \multirow[t]{2}{*}{ MONTH } & \multicolumn{4}{|c|}{ Mean MPN/100 ml } \\
\hline & INFLUENT & EFFLUENT & UPSTREAM & DOWNSTREAM \\
\hline Enterococcus & $(n=15)$ & $(n=15)$ & $(n=15)$ & $(n=15)$ \\
\hline May $(n=8)$ & $2.90 E+05$ & $4.30 E+03$ & $4.08 \mathrm{E}+03$ & $2.33 \mathrm{E}+03$ \\
\hline June $(n=8)$ & $3.89 E+05$ & $4.70 E+02$ & $1.73 E+04$ & $2.10 E+03$ \\
\hline July $(n=12)$ & $9.67 E+05$ & $1.03 E+03$ & $2.85 \mathrm{E}+04$ & $6.16 \mathrm{E}+03$ \\
\hline August $(n=8)$ & $1.75 E+06$ & $3.33 \mathrm{E}+03$ & $1.99 E+04$ & $1.59 E+03$ \\
\hline September $(n=8)$ & $3.19 E+06$ & $2.62 E+03$ & $2.04 \mathrm{E}+04$ & $3.87 \mathrm{E}+03$ \\
\hline October $(n=8)$ & $2.53 \mathrm{E}+06$ & $2.60 E+02$ & $4.73 E+04$ & $2.95 \mathrm{E}+03$ \\
\hline November $(n=8)$ & $2.60 E+06$ & $5.45 \mathrm{E}+03$ & $6.39 E+04$ & $1.91 E+04$ \\
\hline Arithmetic mean (Overall) & $1.63 \mathrm{E}+06$ & $2.39 E+03$ & $2.87 E+04$ & $5.50 \mathrm{E}+03$ \\
\hline Geometric mean (Overall) & $1.12 \mathrm{E}+06$ & $1.36 \mathrm{E}+03$ & $1.66 \mathrm{E}+04$ & $3.42 \mathrm{E}+03$ \\
\hline \multicolumn{5}{|l|}{ E. coli } \\
\hline May $(n=8)$ & $2.19 \mathrm{E}+06$ & $1.15 E+03$ & $2.04 \mathrm{E}+04$ & $4.81 E+03$ \\
\hline June $(n=8)$ & $1.80 \mathrm{E}+06$ & $2.60 \mathrm{E}+02$ & $2.73 \mathrm{E}+04$ & $3.72 \mathrm{E}+03$ \\
\hline July $(n=12)$ & $4.38 \mathrm{E}+06$ & $4.43 \mathrm{E}+02$ & $4.56 \mathrm{E}+04$ & $7.52 \mathrm{E}+03$ \\
\hline August $(n=8)$ & $3.62 \mathrm{E}+06$ & $1.34 \mathrm{E}+03$ & $4.26 \mathrm{E}+04$ & $5.33 \mathrm{E}+03$ \\
\hline September $(n=8)$ & $4.84 \mathrm{E}+06$ & $5.09 E+03$ & $1.05 E+05$ & $2.22 \mathrm{E}+04$ \\
\hline October $(n=8)$ & $4.84 \mathrm{E}+06$ & $2.80 E+03$ & $1.34 \mathrm{E}+05$ & $7.22 \mathrm{E}+03$ \\
\hline November $(n=8)$ & $4.84 \mathrm{E}+06$ & $5.29 E+03$ & $2.46 \mathrm{E}+06$ & $4.20 E+04$ \\
\hline${ }^{\mathrm{a}}$ Arithmetic mean (Overall) & 3.83E+ 06 & $2.21 E+03$ & $3.81 \mathrm{E}+05$ & $1.29 \mathrm{E}+04$ \\
\hline Geometric mean (Overall) & $3.39 E+06$ & $1.15 E+03$ & $5.75 E+04$ & $7.46 \mathrm{E}+03$ \\
\hline
\end{tabular}

${ }^{a}$ This mean was used to compute the risk of infection; $\mathrm{n}=$ number of samples collected/month, i.e. a single $500 \mathrm{ml}$ sample was collected every $2 \mathrm{weeks}$ from 4 sample sites to yield 8 samples per month except in July where samples were taken thrice to yield 12 samples. NB: the same samples were used to isolate E.coli/ Enterococcus, total number of samples used was 60 
$(\mathrm{n}=150)$ sites were confirmed (uidA gene) using realtime PCR. The isolates were then delineated into different pathotypes using virulence genes. The percentage prevalence of the different pathotypes is shown in Fig. 1.

All the assayed virulence genes were detected except for the stx gene of Shiga toxin-producing E. coli (STEC). The eagg (309/580; 53.3\%) and IpaH (128/580; 22.1\%), representing the EAEC and EIEC pathotypes, were the most prevalent genes from all sampled sites.

Also, 579 Enterococcus isolates were confirmed (tuf gene) using real-time PCR. The isolates were then delineated into different species using species-specific primers. The prevalence of the different species is shown in Fig. 2. E. faecalis (50.4\%) and E. faecium (31.4\%) were the most prevalent species.

\section{Probability of infection with $E$. coli following exposure to polluted river water and wastewater}

The predicted $\mathrm{Pi}$ assuming both exposure scenarios is shown in Fig. 3.

The daily $\mathrm{Pi}$ with pathogenic E. coli following intentional uptake of $100 \mathrm{~mL}$ of the river water upstream and downstream from the investigated WWTP was found to be 97.6 and $90.8 \%$, respectively. The monthly Pi was calculated for the upstream and downstream sites assuming once-off accidental ingestion of $1 \mathrm{~mL}$ or intentional ingestion of $100 \mathrm{~mL}$ based on monthly average E. coli counts obtained over the 7 months (Fig. 3). When assuming a $1 \mathrm{~mL}$ exposure volume, the monthly Pi for upstream and downstream sites ranged from 55.1 to $92.9 \%$ and 26.8 to $65.3 \%$, respectively.
The Pi was also calculated for the workers at the WWTP who were exposed to raw influent or final effluent based only on incidental ingestion or inhalation of a $1 \mathrm{~mL}$ contact volume (Fig. 4).

The projected daily and annual $\mathrm{Pi}$ with pathogenic $E$. coli for workers at the WWTP ranged from 0 to $1.2 \%$ for ingestion of effluent water and from $23.8-100 \%$ for accidental ingestion of raw influent water. The monthly Pi of workers at the WWTP based on accidental ingestion of raw influent or final effluent water ranged from 91.9-94.5\% and 3.1-32.6\% (Fig. 4). There was a significant difference between the Pi calculated for the upstream site and downstream site and the influent site and effluent site $(p<0.05)$. No statistically significant differences were observed in the $\mathrm{Pi}$ between adjacent months at the upstream and downstream sites, after exposure to $1 \mathrm{~mL}$ of polluted water $(p>0.05)$ or deliberate consumption of $100 \mathrm{~mL}$ of the water $(\mathrm{p}>0.05)$.

\section{Discussion}

Exposure to microbial pathogens in polluted waters has severe public health consequences. The current study evaluated the possible health hazards from the use of polluted river water by communities (mostly informal settlements) living upstream and downstream of a major WWTP, using E. coli as a model organism. The study also evaluated the risk of infection in WWTP workers, due to probable exposure to polluted aerosols. The mean microbial count at all the sampling sites exceeded the South African and WHO recommended limits for drinking and recreational water. Quantitative microbial risk

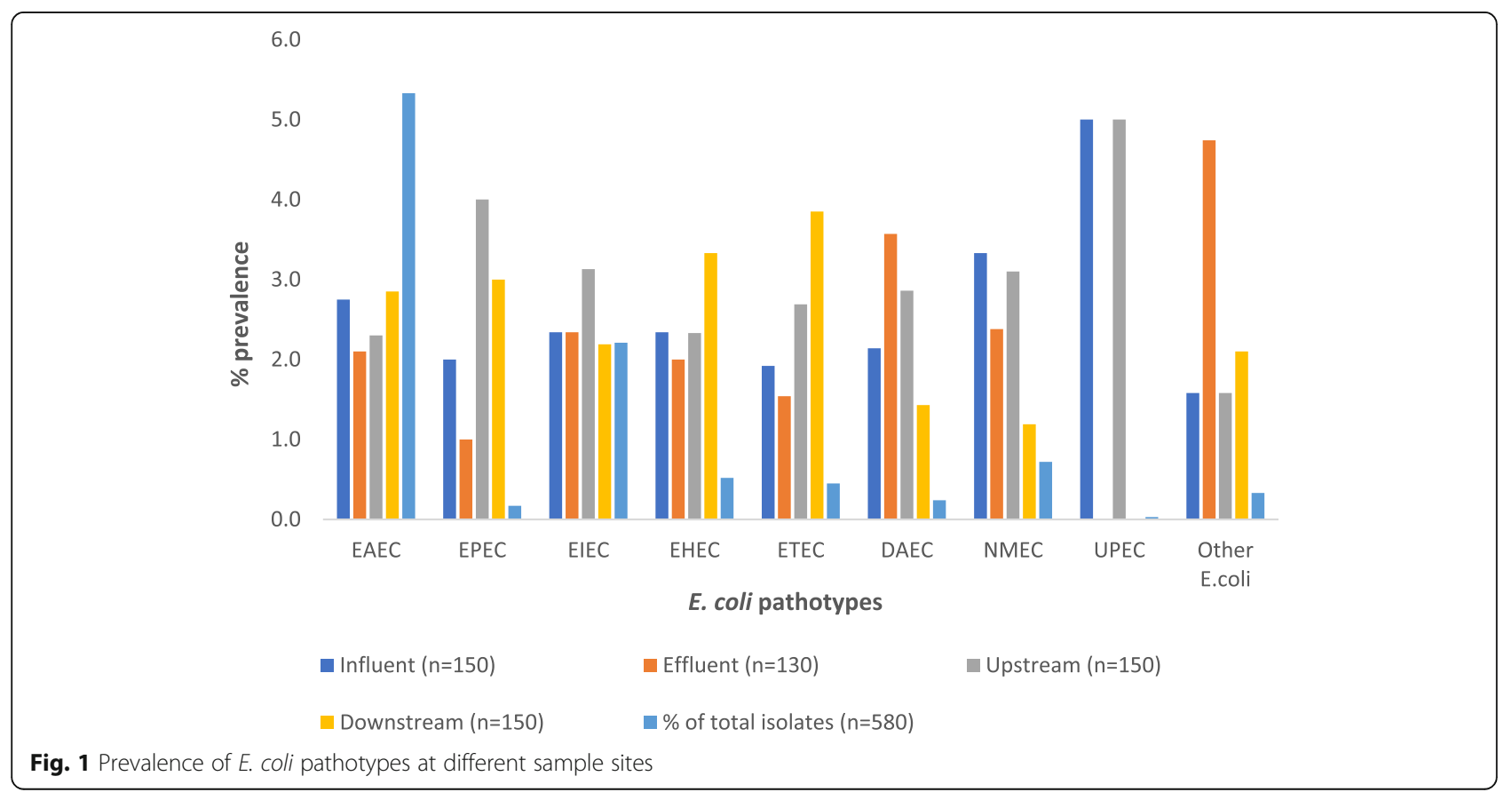




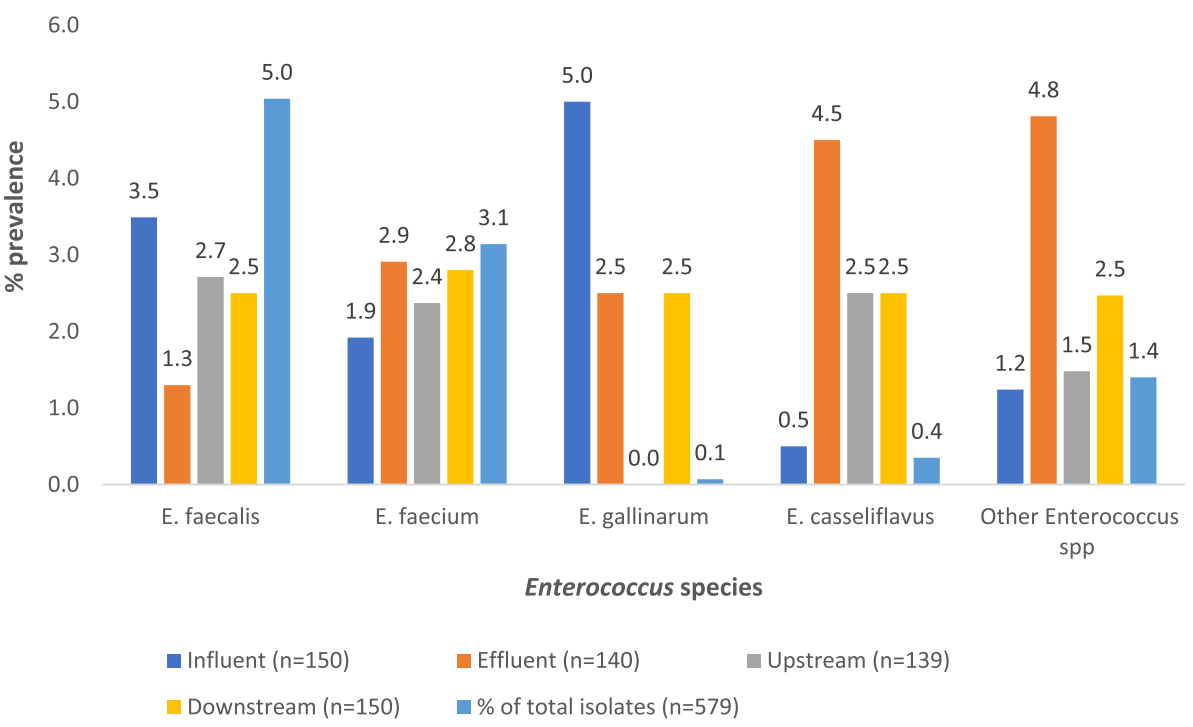

Fig. 2 Prevalence of Enterococcus spp. at different sample sites

assessment revealed that the waters upstream and downstream from the WWTP presented a high risk of infection for surrounding populations using these waters. The WWTP workers were also at risk of developing an infection from exposure to aerosols within the plant if they did not observe the strict use of personal protective equipment.

\section{Mean concentrations of $E$. coli and Enterococcus spp.}

The mean E. coli and Enterococcus concentrations (Table 1) were above the established South African limits of 1000 $\mathrm{CFU} / 100 \mathrm{~mL}$ and $0 \mathrm{CFU} / 100 \mathrm{~mL}$ for discharged wastewater and potable water for household use, respectively [24]. Based on the same guidelines, the concentrations of both organisms also exceeded the allowable limits for use in leisure and farming practices in South Africa. The counts recorded at the river sites also exceeded international standards. For example, the US Environmental Protection Agency (US EPA) recommends that the geometric mean of E. coli and Enterococcus in freshwater meant for recreational purposes should not exceed $126 \mathrm{CFU} / 100 \mathrm{~mL}$ and $35 \mathrm{CFU} / 100 \mathrm{~mL}$, respectively [25]. Similarly, the WHO recommends that E. coli should not be detected in any water $(100 \mathrm{~mL})$ meant for human consumption [26]. This means that the river water upstream and downstream of the WWTP should be classified as generally unsafe for bathing and drinking purposes.

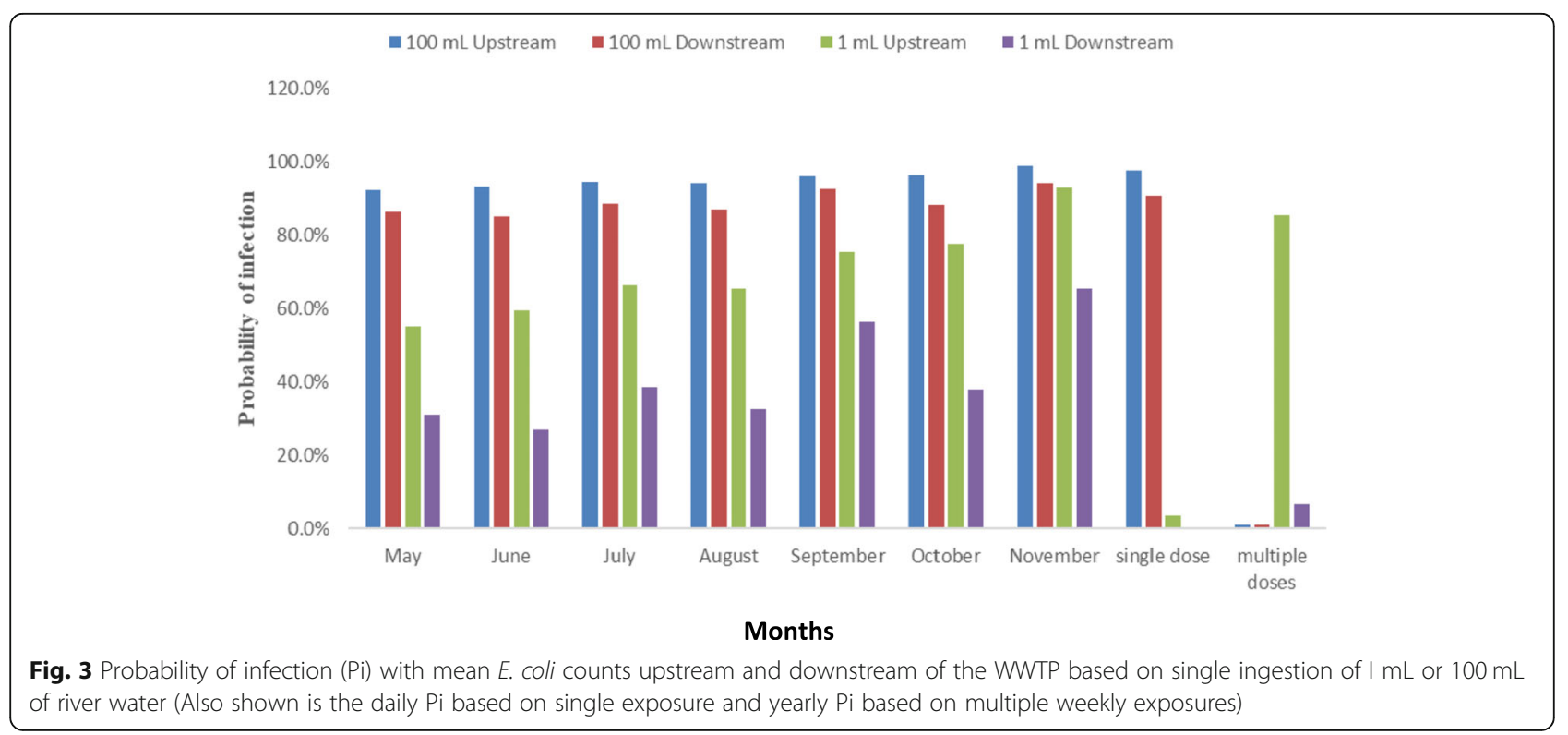




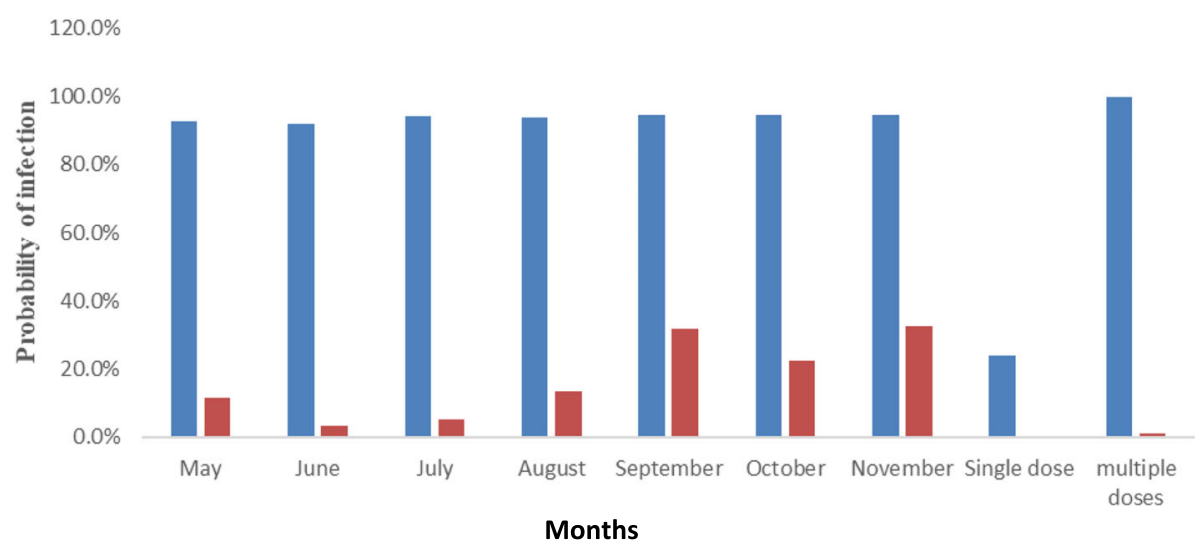

Fig. 4 Probability of infection with mean E. coli counts based on accidental ingestion of $1 \mathrm{~mL}$ raw influent or $1 \mathrm{~mL}$ final effluent water in a WWTP (Also shown is the daily Pi based on single exposure and yearly Pi based on multiple weekly exposures)

The area further up from the upstream sampling site is characterized by many industrial activities. This has led to the development of numerous informal settlements by the people working in the factories, and these settlements are located on one of the main tributaries of the Msunduzi River. Without adequate waste management facilities, these informal settlements dispose of their household and personal waste directly into the surface water body, resulting in high faecal pollution. Apart from the informal settlements, this area is also characterized by some agricultural activities around the river. The direct discharge of waste into the river and surface runoff from these agricultural activities could have contributed, as nonpoint sources of pollution, to the statistically significantly higher microbial counts recorded at the upstream site compared to the downstream site. Informal settlements [10] and agricultural activities [27] have been shown to negatively impact the quality of surface water bodies. Also, the lower microbial count at the downstream site compared to the upstream site could have resulted from the dilution effect from the large volume of treated wastewater discharged from the WWTP.

\section{Molecular characterization of E. coli and Enterococcus spp.} The continuous monitoring of wastewater treatment plants and their effectiveness in removing microbial pathogens remains an area of significant interest. E. coli remains the most widely used indicator of recent faecal contamination in aquatic environments and is often used to monitor WWTPs effluents [5]. Despite the role played by WWTPs in treating wastewater before discharge into receiving surface waters, the importance of WWTPs in the dissemination of pathogens into surface water has been reported in previous studies $[8,9]$. In the current study, seven groups of pathogenic E. coli (InPEC: EAEC, EPEC, EIEC, EHEC (O157H7), ETEC, DAEC; and ExPEC: NMEC and UPEC) were isolated from surface waters (upstream and downstream) as well as at the influent and final effluent of the studied WWTP. The prevalence of the pathogenic E. coli strains varied across the different sampling points (Fig. 1). Interestingly all pathogenic E. coli strains were detected at all sampling points, including surface waters upstream and downstream of the wastewater treatment plant. This points to the contamination of the Msunduzi River with pathogenic E. coli strains upstream and downstream of the studied WWTP, presenting a significant public health risk, especially for communities living along the riverbanks. These findings also imply that $E$. coli strains which are probably released from the wastewater treatment process could survive in the environment.

In the current study, InPEC were the predominant isolates detected across all sampled points with a frequency of detection ranging from 1.7-53.3\%. The InPEC isolates accounted for $89.1 \%$ of all the isolates with ExPEC accounting for $7.6 \%$ and the uncharacterized isolates 3.3\%. These findings are contrary to the findings of an Australian study in which no InPEC isolates were detected in different treatment tanks of four STPs [28]. The same study reported a higher prevalence of ExPEC isolates (59.5\%), specifically UPEC isolates across the four STPs. InPEC isolates have, however, been shown to survive the wastewater treatment process. A study done in Gauteng province on six WWTPs tested water samples, for EPEC, EIEC, EAEC, EHEC and ETEC, from raw sewage, primary, secondary, and tertiary effluents. InPEC isolates were detected in all 6 WWTPs [13]. All five pathotypes were detected at various stages of the treatment process, including in the tertiary effluent, showing that InPEC isolates do survive the wastewater treatment process. Another study done in South Africa focused on pathogenic E. coli from the final effluents of two WWTPs in 
the Eastern Cape province and reported a higher proportion of ExPEC isolates (56.5\%) than InPEC (16,6\%) isolates [9]. In a study by Frigon et al. (2013), the reported proportions of InPEC and ExPEC were 10 and 24\% respectively. The differences in the proportions of InPEC to ExPEC between the current study and the other studies could be due to the number of medical facilities in the uMgungundlovu District, most of whose effluent is treated at the WWTP we investigated. The district has nine major hospitals, 46 fixed clinics, and three community health centres.

The detection of eaeA $+f l i C H 7$ genes, which are characteristics of EHEC isolates, specifically O157:H7, at all sampled sites is a cause for concern (Fig. 1). The EHEC group has been recognized as the universal cause of serious human gastrointestinal diseases [29]. EHEC O157: $\mathrm{H} 7 / \mathrm{H}(-)$ (nonmotile) can occur as variants that either possess the Shiga toxin gene (stx) or lack it in clinical or environmental isolates [30]. The stx (stx1 and stx2) genes [31] together with the intimin protein (eaeA gene), which is involved in bacterial adherence, are some of the virulence determinants that can be used to identify EHEC strains. The $\mathrm{fliCH} 7$ gene encodes the structural flagella antigen $\mathrm{H} 7$ in $E$. coli and is used to identify the OH157: $\mathrm{H} 7$ serotype [32]. The stx, eaeA and fliCH7 genes were used in this study for the molecular identification of OH157: H7. All the detected OH157: H7 strains were, however, stx negative. Reports on the isolation of O157:H7 are rare in South Africa, particularly from environmental samples [33, 34] . Muller et al. [35] used immunomagnetic separation (IMS) in combination with selective media and other techniques to evaluate the incidence of E. coli O157:H7 in sewage and environmental water samples in Gauteng South Africa. The authors only found the E. coli $\mathrm{O} 157: \mathrm{H} 7$ in $1.1 \%$ of the 16 sewage samples and did not find any in the 40 river water samples analyzed. In an earlier study, Müller et al. [36] assessed the presence of $E$. coli $\mathrm{O} 157: \mathrm{H} 7$ in river water used for domestic purposes in the same province. Out of the 204 water samples assayed, none of the 633 suspected E. coli $\mathrm{O} 157: \mathrm{H} 7$ had all the requisite virulence determinants necessary for E. coli $\mathrm{O} 157: \mathrm{H} 7$ classification. In another study on $E$. coli $\mathrm{O} 157: \mathrm{H} 7$ that included an investigation of 180 drinking water samples from the Amathole District in South Africa, only 4 (2.2\%) were confirmed to be positive using molecular techniques [33]. The detection of $E$. coli $\mathrm{O} 157: \mathrm{H} 7$ in all the sampled sites in the present study, albeit at very low prevalence $(5.2 \%)$, is consistent with the generally low occurrence of the organisms in environmental samples in South Africa [34].

The EAEC were the most prevalent DEC pathotype across all sampled points (53.3\%; 309/580 isolates), followed by EIEC (22.1\%; 128 isolates), EHEC (5.2\%; 30 isolates), ETEC (4.5\%; 26 isolates), DAEC (2.4\%; 14), and atypical EPEC/EHEC $(1.7 \% ; 10)$. The proportions of
DEC seem to vary across different studies. Osińska et al. [37] characterized E. coli obtained from raw and processed wastewater from a WWTP and its receiving waters in Poland using antibiotic resistance and virulence genes. From the 317 E. coli isolates assayed in their study, they found the following prevalences: typical EPEC bfpA (65\%), eaeA (39\%); ETEC, st (56\%); EHEC, stx (9\%); EIEC, ipaH (5\%); EAEC, CVD432 (28\%). The observed prevalence of the different pathotypes was different from that observed in the current study. The differences could be due to the difference in the target genes used, the number of isolates assayed and the geographical location. Omar and Barnard [13] developed an 11-genesingle-step multiplex PCR for the detection of DEC in clinical and environmental water samples. In their study they examined 291 wastewater samples for DEC and found the following prevalences: EPEC/EHEC (eaeA gene) 40\%, EAEC (eagg) 35\%, EHEC (stx1/stx2) 12.4\%, ETEC $(l t / s t) 11.3 \%$ and EIEC (ial) 2\%.. The study by Omar and Barnard [13] did not assay for DAEC. Another study done in Tunisia analyzed 60 wastewater samples from 15 WWTPs targeting the influent and final effluent [38]. The authors found that from the 30 influent samples, ETEC isolates were the most prevalent (53.3\%), followed by EAEC (16.6\%), and EIEC (6.6\%). At the effluent points, the ETEC (53.3\%) was still the most isolated pathotype followed by EAEC (33.3\%) and EIEC (13.3\%). The EHEC was not detected in any of the sampled points. In the study by Adesifoye and Okoh [9] in South Africa, the following proportions of DEC were observed in the final effluent of two WWTPs from a total of 223 E. coli isolates: atypical EPEC/EHEC (7.6\%), ETEC (1.4\%), and EAEC (7.6\%). The EIEC and DAEC were not detected at all. Our study is one of the few from this region to report on the presence of DAEC in environmental water samples. The prevalence of DEC in environmental water samples possibly varies from region to region and is probably dependent on the communities served by the WWTPs, among other factors.

Characterization of the enterococci, according to species, revealed the presence of four species at the assayed sites. E. faecalis (50.4\%) was the dominant species across all sampled points, followed by E. faecium (31.4\%) which was, however, the most abundant from effluent samples (Fig. 2). Our findings are similar to those of a study done in Ireland by Cheng et al. [39], which examined the seasonal incidence of E. faecalis and E. faecium in raw and treated effluent as well as from biosolids in four WWTPs. They observed a higher prevalence of E. faecalis at all sampled sites when both species were detected. Similar findings were reported by Alipour et al. [40] in a study done in Iran on surface water (river and coastal) in which they found E. faecalis to be the predominant species (68.6\%) out of a total of 70 Enterococcus isolates. 
The other species reported in that study were E. faecium (20\%), E. gallinarum (7.1\%), and E. casseliflavus (4.3\%). This varies with findings from our study as $E$. casseliflavus (3.5\%) was more prevalent than E. gallinarum (0.7\%) (Fig. 2). Iweriebor et al. [41] conducted a study on enterococci from hospital effluent as well as from the final effluent of a WWTP in Eastern Cape, South Africa. From a total of 62 confirmed Enterococcus isolates, they found E. faecalis (48.39\%) as the dominant species followed by $E$. durans (24\%) but did not identify other species, a finding which differed from our study.

The discrepancies between the current study and other studies could be due to several factors like the number of samples analyzed, the number of isolates characterized, the isolation and characterization methods used, the frequency of sampling, seasonal differences during sampling, wastewater treatment processes used, and other physicochemical parameters of the water sampled, among others.

\section{Probability of infection with $E$. coli following exposure to polluted river water and wastewater}

A total of $580 \mathrm{E}$. coli isolates were analyzed for their pathogenic potentials, using specific virulence genes. Although this number was large, it was not representative of the total number of $E$. coli isolated in the entire study. Therefore, to calculate the risk of infection in this study, it was assumed that $8 \%$ of the mean E. coli concentration was pathogenic, based on literature [10, 22]. The hazards considered for the QMRA were the six diarrhoeagenic $E$. coli (DEC) pathotypes for which the incidence and probability of infection due to contact with wastewater were estimated. All these pathotypes are characterized by the fecal-oral transmission route. The DEC pathotypes were chosen for QMRA based on their reported low infectious doses, ease of detection, and quantification [2, 22]. The pathogens can also persist for weeks in the environment and are difficult to inactivate or remove adequately using conventional wastewater treatment processes $[8,9,37]$.

For the upstream and downstream sites based on the unintentional consumption of $1 \mathrm{~mL}$ or the deliberate consumption of $100 \mathrm{~mL}$ of river water, the results showed that the annual $\mathrm{Pi}$ with pathogenic E. coli was above that recommended for potable water $[10,4]$ by the WHO [42]. The Pi was significantly higher in the upstream site than downstream site assuming exposure to either a $1 \mathrm{~mL}$ or $100 \mathrm{~mL}$ volume, implying that communities upstream of the WWTP were at greater risk of infection. Assuming exposure to $1 \mathrm{~mL}$ every week for a year ( 52 weeks), the probability of infection at the downstream site was found to be $6.6 \%$ compared to $85.5 \%$ at the upstream site (Fig. 3). These results are comparable to work done in Gauteng, South Africa where the health hazards in four rivers and their associated WWTPs, utilizing waterborne Salmonella enterica serovar Typhimurium, Shigella dysenteriae, and Vibrio cholerae, was determined [43]. The authors reported that the day-today and yearly joint risk of infection resulting from the consumption of $1 \mathrm{~mL}$ of raw water was higher at the upstream than downstream sites [43]. The study also described the hazard resulting from drinking $50 \mathrm{~mL}$ and $100 \mathrm{~mL}$ as having an annual joint pathogen infection risk of $100 \%$. The current study also recorded an annual risk of infection of $100 \%$ following exposure to $100 \mathrm{~mL}$ of polluted untreated river water, for both the upstream and downstream sites (Fig. 3). In another study done in South Africa at sites along the Apies river, the risk of infection with $E$. coli ranged from 6 to $84 \%$ across the sampled sites, assuming a one-off intake of $100 \mathrm{~mL}$; the risk increased to $100 \%$ at eight of the ten sites assuming multiple exposures (weekly) over 6 months [10]. These findings are like those in the current study regarding the Pi following multiple exposures and assuming a $100 \mathrm{~mL}$ ingestion volume (Fig. 3). However, the risk of infection was calculated over a more extended period (52 weeks) in the present study. Assuming a single dose of $100 \mathrm{~mL}$, the monthly Pi ranged from 92.3 to $98.8 \%$ for the upstream site and 85 to $94.2 \%$ for the downstream site. This is higher than the Pi stated by Abia et al. [10] mainly because they sampled from more sites, some of which were not near WWTPs and had a lower bacterial load. The findings of the current study also differ and are higher than those reported by two studies done in the Olifants River, South Africa [44, 45]. Genthe et al. [44] stated that the Pi with E. coli fluctuated from 8 to $80 \%$ across the 12 studied sites while le Roux et al. [46] described a combined $\mathrm{Pi}$ of between 1 and $26 \%$ for the seven pathogens investigated due to the drinking of 100 $\mathrm{mL}$ of unprocessed water from the upper Olifants River. Based on E. coli as the surrogate for pathogens, the Pi in the study of le Roux et al. [46], at some locations was approximately $80 \%$ assuming a once-off exposure incident. This is lower than the $\mathrm{Pi}$ in the current study, which stood at 90.8 and $97.6 \%$ for the downstream and upstream sites, respectively (Fig. 3).

Wastewater treatment plants are considered a potential hazard for human health, particularly for WWTP workers [47]. The hazards are considered to be dependent on the characteristics of the wastewater, method of treatment, type of apparatus used, as well as the meteorological and climatic conditions $[46,47]$. WWTP workers may be exposed to biohazards through bioaerosols, aeroallergens, and other airborne organic particles which can potentially cause gastroenteritis and pulmonary diseases [17, 47]. Despite the identification of health hazards connected to exposure to aerosols, risk assessment is still challenging as the degree of exposure to bioaerosols in WWTP varies depending on various factors [48]. There is a paucity of data 
regarding the risk of exposure plant workers face in WWTPs, especially from developing countries [48]. Thus, the current study also estimated the occupational risk of infection with pathogenic $E$. coli for workers that may be exposed to wastewater in the WWTP. The risk assessment was surmised on the accidental ingestion of $1 \mathrm{~mL}$ of either influent or effluent water during normal work activities. The Pi resulting from a once-off unintentional consumption of $1 \mathrm{~mL}$ of effluent was 0 , and $23.8 \%$ for raw influent water (Fig. 4). Multiple weekly exposures of the same volume over a year resulted in an estimated $\mathrm{Pi}$ of 1.2 and $100 \%$ for the effluent and influent, respectively. The low Pi observed for the effluent is due to the significantly lower microbial load recorded in the final effluent throughout the study (Table 1), pointing to the efficiency of the WWTP in reducing the microbial load. The monthly Pi was calculated assuming a single exposure event, i.e. accidental consumption of $1 \mathrm{~mL}$ of water; generally, the estimated risk was significantly higher for influent water (Fig. 4). Bioaerosol emissions have been found to be the highest in pretreatment and aerated grit separation stages and to decrease in subsequent treatment stages [49]. This implies WWTP workers are more likely to be exposed to bioaerosols from raw influent water than effluent water, cementing the need for strict adherence and proper use of personal protective equipment. Other exposure control measures in WWTPs could include preventing workers from spending long periods in areas with high bioaerosol emissions [17].

It should be noted, however, that the $8 \%$ pathogenic potential assumed in the current study may have underestimated or overestimated the risk of infection [6]. Also, the parameters used in the current study were for E. coli O157:H7. Therefore, the risk of infection estimated in this study should not be generalized for all other pathogenic microbes that are present in wastewater and polluted river waters. It was also assumed that every exposed individual would have the same chance of getting sick. This is not always the case as other factors like the age, the immune status, infective dose of the specific pathogen (among others) could influence whether an individual develops an infection following exposure to a pathogen. Thus, we recommend that future studies look at using other pathogens.

\section{Conclusion}

The findings of the present study show that the investigated WWTP and its associated surface water had a high percentage of pathogenic E. coli. The river water upstream and downstream of the investigated WWTP is contaminated with high concentrations of fecal indicator bacteria, and there is a substantial risk of infection with pathogenic E. coli for people that use these water sources. An occupational health hazard was noted for workers at the WWTP, especially if they were exposed to raw influent wastewater. The study brings to light the need for relevant authorities to work towards ensuring that all communities are supplied with clean water for domestic and recreational purposes, and seeks to encourage the development of mitigation strategies in resource-limited communities. The study further highlights the need to institute occupational health and safety measures for WWTP workers.

\section{Methods}

\section{Study site and sample collection}

The WWWTP serves the uMsunduzi municipality and has a biological treatment capability of $65 \mathrm{Ml} /$ day. The WWTP is located along the uMsunduzi river and uses aeration basins for organic nutrient elimination and clarifiers for the separation process. Clarified effluent undergoes tertiary treatment, which involves chlorination [50]. The uMsunduzi River passes through Pietermaritzburg the provincial capital of KwaZulu-Natal. It receives runoff from the municipality, rural communities, agricultural areas, and treated effluent from the investigated WWTP [15]. The river is also one of the main tributaries of the Umgeni River, both rivers are key sources of water that is used for recreational, domestic, agricultural, and industrial purposes in KwaZulu-Natal [15]. The climate in KwaZulu-Natal is typically tropical to subtropical with rainfall falling throughout the year, with the least rainfall experienced between May and August. Water sampling was done fortnightly over 7 months (May 2018 to November 2018). A total of 60 grab water samples were collected in sterile $500-\mathrm{mL}$ containers, from the influent $\left(29^{\circ} 36^{\prime} 3.70^{\prime \prime} \mathrm{S} 30^{\circ} 25^{\prime} 41.71^{\prime \prime} \mathrm{E}\right)$ and final effluent $\left(29^{\circ} 35^{\prime} 49.97^{\prime \prime} \mathrm{S} 30^{\circ} 26^{\prime} 19.74^{\prime \prime} \mathrm{E}\right)$ of a major WWTP and the Msunduzi River, upstream $\left(29^{\circ} 36^{\prime}\right.$ $\left.10.73^{\prime \prime S} 30^{\circ} 25^{\prime} 29.97^{\prime \prime} \mathrm{E}\right)$, and downstream (29 $36^{\prime} 27.54^{\prime \prime}$ S $30^{\circ} 27^{\prime} 0.76^{\prime \prime} \mathrm{E}$ ) from the WWTP in uMgungundlovu District, in KwaZulu-Natal Province, South Africa. Fifteen samples were collected from each sampling site. Water samples were transported to the research laboratory at $4{ }^{\circ} \mathrm{C}$ for subsequent microbial analysis.

\section{Fecal indicator analysis}

Detection and quantification of E. coli and Enterococcus were performed using the Colilert ${ }^{\circ}-18$ / Quanti-Tray ${ }^{\circ}$ 2000 system and Enterolert ${ }^{\circ} /$ Quanti-Tray $^{\circ} 2000$ sys- $^{-}$ tems, respectively according to the manufacturer's instructions (IDEXX Laboratories (Pty) Ltd., Johannesburg, South Africa). Positive results for both organisms were denoted by fluorescent blue wells under UV light at $300 \mathrm{~nm}$. Positive wells were then used to determine the most probable number (MPN) of each organism in $100 \mathrm{~mL}$ of water sample (MPN/100 mL). Both Quanti-Tray methods had a limit of detection equivalent to $4.84 \mathrm{E}+06 / 100 \mathrm{ml}$. 
Isolation of E. coli and Enterococcus spp.

Positive well contents were sub-cultured onto selective media as previously described [51] and. E. coli was subcultured on Eosin Methylene Blue (EMB) and incubated at $37^{\circ} \mathrm{C}$ for 18 - $24 \mathrm{~h}$ while Enterococcus was subcultured on Bile Aesculin Azide Agar (Merck, Germany) or Slanetz and Bartley agar (Merck, Germany) and incubated at $41{ }^{\circ} \mathrm{C}$ for $24 \mathrm{~h}-48 \mathrm{~h}$. At least ten distinct colonies representing each sampling site were randomly selected from each media type and further sub-cultured onto respective selective media to obtain pure colonies. Presumptive isolates were stored in $20 \%$ glycerol stocks at $-80^{\circ} \mathrm{C}$ for further investigation.

\section{DNA extraction and molecular confirmation}

Bacterial DNA for both E. coli and Enterococcus spp. was extracted using a standard heat-lysis protocol. Molecular confirmation of all isolates was done using real-time PCR, where the uidA ( $\beta$-D glucuronidase) gene was used for $E$. coli [52] and the tuf gene for enterococci [53]. E. coli (ATCC 25922) and E. faecalis (ATCC 51299) served as positive controls.

\section{Determination of $E$. coli pathotypes}

Delineation of $E$. coli into various pathotypes was done using real-time PCR. The pathotypes assayed for included EPEC, ETEC, EAEC, EIEC, DAEC, EHEC, NMEC, and UPEC. Conventional PCR was used to assay the DAEC and UPEC pathotypes. All reactions included a no-template control consisting of the reaction mixture. The primers for virulence genes and reference strains used in this study are shown in Table S1 (Supplementary materials). All real-time PCR assays consisted of $5 \mu \mathrm{L} 2 \mathrm{x}$ Luna universal master mix (New England Biolabs, South Africa), $0.5 \mu \mathrm{L}(1.25 \mu \mathrm{M})$ of each primer, $3 \mu \mathrm{L}$ of template DNA which was topped up to $10 \mu \mathrm{L}$ with nucleasefree water except for the St gene where $1 \mu \mathrm{L}(2.5 \mu \mathrm{M})$ of each primer and $2 \mu \mathrm{L}$ of genomic DNA was used. The following real-time PCR settings were used: initial hold at $50{ }^{\circ} \mathrm{C}$ for $2 \mathrm{~min} ; 35$ cycles \{denaturation at $95^{\circ} \mathrm{C}$ for 2 min; annealing at $60^{\circ} \mathrm{C}$ for $15 \mathrm{~s}$; extension at $72^{\circ} \mathrm{C}$ for $10 \mathrm{~s}$; ; final extension at $72{ }^{\circ} \mathrm{C}$ for $5 \mathrm{~min}$. All real-time PCR assays were done on an Applied Biosystems QuantStudio 5 Real-time PCR system (Thermo Fisher Scientific, Waltman, Massachusetts, USA).

Conventional PCR was done in a $20 \mu \mathrm{L}$ reaction volume with $2 \mu \mathrm{L}$ of genomic DNA, $10 \mu \mathrm{L}$ of One Taq master mix (New England Biolabs, South Africa), $0.5 \mu \mathrm{L}$ $(0.6 \mu \mathrm{M})$ of each primer, plus $7 \mu \mathrm{L}$ of nuclease-free water. The PCR reactions were as follows: initial denaturation $\left(94^{\circ} \mathrm{C}, 30 \mathrm{~s}\right), 35$ cycles of denaturation $\left(94^{\circ} \mathrm{C}\right.$, $15 \mathrm{~s})$, annealing $\left(59^{\circ} \mathrm{C}, 30 \mathrm{~s}\right)$ for the daaE gene (DAEC), $\left(55^{\circ} \mathrm{C}\right.$, 30s) for the papC gene (UPEC), extension $\left(68^{\circ} \mathrm{C}\right.$, $45 \mathrm{~s})$, final extension $\left(68^{\circ} \mathrm{C}, 5 \mathrm{~min}\right)$. PCR products were run on a $1 \%$ ethidium bromide-stained gel with a $100 \mathrm{bp}$ ladder (Thermo Fisher Scientific, USA) in TAE buffer for $1 \mathrm{~h}$ at $100 \mathrm{~V}$ and visualized using a Gel Doc ${ }^{\text {Tin }} \mathrm{XR}+\mathrm{im}$ aging system (Bio-Rad, South Africa).

\section{Speciation of Enterococcus isolates}

Enterococcus isolates were further characterized into various species using real-time PCR, according to [54] (Table S2, Supplementary materials). All reactions included a no template control. All PCR assays comprised $5 \mu \mathrm{L}$ of Luna universal master mix $0.5 \mu \mathrm{L}(1.25 \mu \mathrm{M})$ of the individual primer, $3 \mu \mathrm{L}$ of template DNA, and topped up to $10 \mu \mathrm{L}$ with nuclease-free water. The PCR conditions were initial hold at $50^{\circ} \mathrm{C}(2 \mathrm{~min}) ; 35$ cycles \{denaturation at $95^{\circ} \mathrm{C}(2 \mathrm{~min})$; annealing at $60^{\circ} \mathrm{C}(15 \mathrm{~s})$; extension at $\left.72{ }^{\circ} \mathrm{C}(10 \mathrm{~s})\right\}$; final extension at $72^{\circ} \mathrm{C}$ for 5 min. A melt curve was prepared, according to Molechan et al. [55]. All qPCR reactions were done on the Applied Biosystems QuantStudio 5 Real-time PCR system.

\section{Risk assessment}

The health hazard related to exposure to waterborne E. coli at the WWTP and its associated surface water was computed using a beta-Poisson response model for E. coli O157:H7. The probability of infection (Pi) was based on the unintentional or deliberate consumption of predetermined quantities of river water associated with the studied WWTP. The Pi with pathogenic E. coli resulting from a single unintentional consumption of $1 \mathrm{~mL}$ and deliberate consumption of $100 \mathrm{~mL}$ of water from the Msunduzi River (upstream and downstream of the WWTP) was calculated for the communities which rely on the river for their domestic and recreational needs. The calculations were based on a once-off exposure (daily risk) and repeated exposure (weekly exposure) over 12 months. Pi was also calculated based only on the unintentional ingestion (through inhalation) of $1 \mathrm{~mL}$ of water by the workers at the WWTP [16]. The Pi was calculated based on the postulation that only $8 \%$ of the total E. coli population was pathogenic [10, 16, 22]. The formulae used to calculate the Pi following the once-off consumption and $\mathrm{Pi}$ ensuing from numerous exposures are presented in Table 2. Manifold exposures were computed weekly $(n=52)$ over 12 months. The pathogen infectivity constants $\beta$ and $\alpha$ are presented in Table 2.

\section{Statistical analysis}

All statistical analysis was done using Microsoft Excel 2018 and Statistical Package for Social Sciences 23 (SPSS, IBM Corporation, Armonk, New York, USA). A paired t-test was used to ascertain for any significant differences in the mean microbial counts and the 
Table 2 Beta-Poisson response model and parameters used for quantitative microbial risk assessment

\begin{tabular}{llll}
\hline Microorganism & Parameters & Dose-response model & References \\
\hline Escherichia coli & $\beta=2.473, a=0.395$ & $P($ inf $)=1-(1+N / \beta)-a$ & {$[16,56]$} \\
& $n=52$ & $P(n)=1-(1-P i n f) n$ & {$[16]$} \\
\hline
\end{tabular}

Key: $P$ (inf) Probability of infection; $P(n)$ annual probability of infection; $N$ dosage (number of microbes ingested); $n$ sum of exposures that occurred

Pi between the sites - upstream and downstream, and influent and effluent. A paired t-test was also done to ascertain any significant differences in the $\mathrm{Pi}$ between adjacent months in the event of accidental ingestion of $1 \mathrm{~mL}$ or intentional ingestion of $100 \mathrm{~mL}$. All statistics were considered significant at $p \leq 0.05$.

\section{Supplementary Information}

The online version contains supplementary material available at https://doi. org/10.1186/s12866-020-02036-7.

Additional file 1 : Table S1: $E$. coli primers and reference strains used in $P C R$ reactions. Table S2: Enterococcus primers and reference strains used in PCR reactions. (DOCX $\mathbf{1 8} \mathbf{k b})$

\section{Abbreviations}

PCR: Polymerase chain reaction; CFU: Colony forming unit; MPN: Most probable number; WWTP: Wastewater treatment plant; qPCR: Quantitative polymerase chain reaction; QMRA: Quantitative microbial risk assessment; EXPEC: Extraintestinal pathogenic E. coli; UPEC: Uropathogenic E. coli; APEC: Avian pathogenic E. coli; NMEC: Neonatal meningitis E. coli; InPEC: Intestinal pathogenic E. coli; DEC: Diarrhoeagenic E. coli; EHEC: Enterohemorrhagic E. coli; EPEC: Entero-pathogenic E. coli; EAEC: Entero-aggregative E. coli; ETEC: Enterotoxigenic E. coli; EIEC: Entero-invasive E. coli; DAEC: Diffusely adherent E. coli

\section{Acknowledgements}

The authors would like to thank all members of the Antimicrobial Research Unit (ARU) for their assistance especially research assistant Purity Zama Kubone.

\section{Disclaimer}

Any opinion, finding, and conclusion or recommendation expressed in this material is that of the authors, and neither the NRF nor the other funding bodies accept any liability in this regard.

\section{Authors' contributions}

Co-conceptualized the study: SYE, AALK, JM. Performed the experiments: JM, AALK. Analyzed the data: JM, AALK, DGA. Wrote the paper: JM. Supervision: SYE, AALK; Funding acquisition: SYE; Undertook critical revision of the manuscript: All. All authors reviewed, edited, and approved the final manuscript.

\section{Funding}

This work is based on the research supported by the South African Research Chairs Initiative of the Department of Science and Technology and National Research Foundation of South Africa (Grant No. 98342) and the National Research Foundation Competitive Grant for Rated Researchers (Grant no. 106063). The funding source was not involved in study design, sample collection, data analysis and interpretation.

\section{Availability of data and materials}

The data generated and analyzed in this study are available upon request.

\section{Ethics approval and consent to participate}

Ethical approval was received from the Biomedical Research Ethics Committee (Reference: BCA444/16 of the University of KwaZulu-Natal. Permission to collect water samples was sought and granted by UMgeni water which owns and operates the investigated WWTP.

\section{Consent for publication}

Not applicable.

\section{Competing interests}

Professor Essack is chairperson of the Global Respiratory Infection Partnership funded by an unrestricted educational grant from Reckitt and Benckiser (Pty.), UK. All other authors declare that they have no conflicting interests regarding the publication of this paper.

Received: 26 June 2020 Accepted: 5 November 2020

Published online: 12 November 2020

\section{References}

1. WHO - UNICEF. Progress on drinking water, sanitation and hygiene [Internet]. Geneva; 2017. 1-116 p. Available from: http://apps.who.int/iris/ bitstream/handle/10665/258617/9789241512893-eng.pdf?sequence=1.

2. Fuhrimann S, Winkler MS, Stalder M, Niwagaba CB, Babu M, Kabatereine NB, et al. Disease burden due to gastrointestinal pathogens in a wastewater system in Kampala, Uganda. Microb Risk Anal [Internet]. 2016;4:16-28. Available from:. https://doi.org/10.1016/j.mran.2016.11.003.

3. Abia ALK, Ubomba-Jaswa E, Momba MNB. Competitive survival of Escherichia coli, Vibrio cholerae, Salmonella typhimurium and Shigella dysenteriae in riverbed sediments. Microb Ecol. 2016 Nov;72(4):881-9.

4. Zhu H, Yuan F, Yuan Z, Liu R, Xie F, Huang L, et al. Monitoring of Poyang lake water for sewage contamination using human enteric viruses as an indicator. Virol J. 2018:15(1):1-9.

5. Karkman A, Do TT, Walsh F, Virta MPJ. Antibiotic-resistance genes in waste Water. Trends Microbiol [Internet]. 2018;26(3):220-8. Available from:. https:// doi.org/10.1016/j.tim.2017.09.005.

6. Katukiza AY, Ronteltap M, van der Steen P, Foppen JWA, Lens PNL. Quantification of microbial risks to human health caused by waterborne viruses and bacteria in an urban slum. J Appl Microbiol. 2013;116(2):447-63.

7. Girardi V, Mena KD, Albino SM, Demoliner M, Gularte JS, de Souza FG, et al. Microbial risk assessment in recreational freshwaters from southern Brazil. Sci Total Environ [internet]. 2019,651:298-308. Available from. https//doi.org/10.1016/jscitotenv.2018.09.177.

8. Anastasi EM, Matthews B, Stratton HM, Katouli M. Pathogenic Escherichia coli found in sewage treatment plants and environmental waters. Appl Environ Microbiol. 2012;78(16):5536-41.

9. Adefisoye MA, Okoh Al. Identification and antimicrobial resistance prevalence of pathogenic Escherichia coli strains from treated wastewater effluents in eastern cape, South Africa. Microbiologyopen. 2016;5(1):143-51.

10. Abia ALK, Ubomba-Jaswa E, Genthe B, Momba MNB. Quantitative microbial risk assessment (QMRA) shows increased public health risk associated with exposure to river water under conditions of riverbed sediment resuspension. Sci Total Environ [Internet]. 2016:566-7:1143-51. Available from:. https://doi.org/10.1016/j.scitotenv.2016.05.155.

11. Riley LW. Pandemic lineages of extraintestinal pathogenic Escherichia coli. Clin Microbiol Infect [Internet]. 2014;20(5):380-90. Available from:. https:// doi.org/10.1111/1469-0691.12646.

12. Sarowska J, Futoma-Koloch B, Jama-Kmiecik A, Frej-Madrzak M, Ksiazczyk M, Bugla-Ploskonska G, et al. Virulence factors, prevalence and potential transmission of extraintestinal pathogenic Escherichia coli isolated from different sources: recent reports. Gut Pathog [internet]. 2019;11(1):1-16. Available from: https://doi.org/10.1186/s13099-019-0290-0.

13. Omar KB, Barnard TG. Detection of diarrhoeagenic Escherichia coli in clinical and environmental water sources in South Africa using single-step 11-gene m-PCR. World J Microbiol Biotechnol. 2014;30(10):2663-71.

14. Gemmell ME, Schmidt S. Is the microbiological quality of the Msunduzi River (KwaZulu-Natal, South Africa) suitable for domestic, recreational, and agricultural purposes? Environ Sci Pollut Res. 2013;20(9):6551-62.

15. Moodley B, Birungi G, Ndungu P. Detection and Quantification of Emerging Organic Pollutants in the Umgeni and Msunduzi Rivers [Internet]. 
Commission WR, editor. Pretoria: WRC Report No.2215/1/16; 2016. Available from: www.wrc.org.za DISCL.

16. Haas CN, Rose JB, Gerba CP. Quantitative Microbial Risk Assessment [Internet] Second Edi. Wiley Blackwell; 2014. Available : https:/doi.org/10.1002/9781118910030.

17. Kindzierski W, M B, Wang X, Wetmore T, Maal-Bared R, Michaels C. Paper No . CSBE15-090 Evidence of Wastewater Treatment Plant Worker Biohazard Exposure and Health Symptom Responses Written for presentation at the CSBE / SCGAB 2015 Annual Conference Delta Edmonton South Hotel, Edmonton, Alberta. In: CSBE/SCGAB 2015 Annual Conference. Alberta: CSBE/SCGAB; 2015. p. Paper No. CSBE15-090.

18. Tomasi C, Sandro F, Kokhanovsky A. In: Tomasi C, Sandro F, Kokhanovsky A, editors. Atmospheric Aerosols: Life Cycles and Effects on Air Quality and Climate: Wiley Blackwell; 2017. p. 704

19. Yapo RI, Koné B, Bonfoh B, Cissé G, Zinsstag J, Nguyen-Viet H. Quantitative microbial risk assessment related to urban wastewater and lagoon water reuse in Abidjan, Côte d'Ivoire. J Water Health. 2014;12(2):301-9.

20. Neudorf KD, Nan Y, Ragush CM, Yost CK, Jamieson RC, Truelstrup L. Science of the Total environment antibiotic resistance genes in municipal wastewater treatment systems and receiving waters in Arctic Canada. Sci Total Environ [nternet]. 2017:598: 1085-94. Available from: https:/doi.org/10.1016/.scitotenv.2017.04.151.

21. Labite H, Lunani I, Van Der Steen P, Vairavamoorthy K, Drechsel P, Lens P. Quantitative microbial risk analysis to evaluate health effects of interventions in the urban water system of Accra, Ghana. J Water Health. 2010;8(3):417-30.

22. Machdar E, van der Steen NP, Raschid-Sally L, Lens PNL. Application of quantitative microbial risk assessment to analyze the public health risk from poor drinking water quality in a low income area in Accra, Ghana. Sci Total Environ [Internet]. 2013;449: 134-42. Available from: https://doi.org/10.1016/.scitotenv.2013.01.048.

23. Sibanda T, Chigor VN, Okoh Al. Seasonal and spatio-temporal distribution of faecal-indicator bacteria in Tyume River in the eastern Cape Province. South Africa Environ Monit Assess. 2013 Aug;185(8):6579-90.

24. Department Of Water Affairs and Forestry D. National Water Resource Strategy. Pretoria, South Africa; 2004.

25. Wade TJ, Pai N, Eisenberg JNS, Colford JM. Do U.S. Environmental Protection Agency water quality guidelines for recreational waters prevent gastrointestinal illness? A systematic review and meta-analysis. Environ Health Perspect. 2003;111(8):1102-9.

26. WHO. World Health Organization. Guidelines for drinking-water quality, 4th edition, incorporating the 1st addendum [Internet]. 2017. Available from: https://www.who.int/water_sanitation_health/publications/drinking-waterquality-guidelines-4-including-1st-addendum/en/.

27. Liang Z, He Z, Zhou X, Powell CA, Yang Y, He LM, et al. Impact of mixed land-use practices on the microbial water quality in a subtropical coastal watershed. Sci Total Environ [Internet]. 2013;449:426-33. Available from: https://doi.org/10.1016/j.scitotenv.2013.01.087.

28. Anastasi EM, Matthews B, Gundogdu A, Vollmerhausen TL, Ramos NL, Stratton $\mathrm{H}$, et al. Prevalence and persistence of Escherichia coli strains with uropathogenic virulence characteristics in sewage treatment plants. Appl Environ Microbiol. 2010;76(17):5882-6.

29. Griffin P, Tauxe R. The epidemiology of infections caused by Escherichia coli O157:H7, and other enterohemorrhagic $E$. coli, and the associated hemolytic uremic syndrome. Epidemiol Rev. 1991;13:60-98.

30. Stephan R, Zhang W, Bielaszewska M, Mellmann A, Karch H. Phenotypic and genotypic traits of Shiga toxin-negative E. coli O157:H7/H(-) bovine and porcine strains. Foodborne Path Dis. 2009;6(2):235-43.

31. Nguyen Y, Sperandio V. Enterohemorrhagic E. coli (EHEC) pathogenesis. Front Cell Infect Microbiol. 2012;2(July):1-7.

32. Wang G, Clark CG, Rodgerst FG. Detection in Escherichia coli of the genes encoding the major virulence factors, the genes defining the 0157:H7 serotype, and components of the type 2 Shiga toxin family by multiplex PCR. J Clin Microbiol. 2002;40(10):3613-9.

33. Abongo BO, Momba MNB. Prevalence and potential link between $\mathrm{E}$. coli 0157:H7 isolated from drinking water, meat and vegetables and stools of diarrhoeic confirmed and non-confirmed HIVAIDS patients in the Amathole District South Africa. J Appl Microbiol. 2008 Aug;105(2):424-31.

34. Lupindu AM. Epidemiology of Shiga toxin-producing Escherichia coli O157: H7 in Africa in review. South African J Infect Dis [Internet]. 2018;33(1):24-30. Available from. https://doi.org/10.1080/23120053.2017.1376558.

35. Muller E, Grabow W, Ehlers M. Immunomagnetic separation of Escherichia coli O157: H7 from environmental and wastewater in South Africa. Water SA. 2004;29(4):427-32

36. Müller E, Ehlers WO, Grabow M. The occurrence of E. coli 0157:H7 in south African water sources intended for direct and indirect human consumption. Water Res. 2001;35(13):3085-8.
37. Osińska A, Korzeniewska E, Harnisz M, Niestępski S. The prevalence and characterization of antibiotic-resistant and virulent Escherichia coli strains in the municipal wastewater system and their environmental fate. Sci Total Environ J. 2016;577:367-75

38. Salem I. Ben, Ouardani I, Hassine M, Aouni M. bacteriological and physicochemical assessment of wastewater in different region of Tunisia: impact on human health. BMC Res Notes. 2011;4(144):1-11.

39. Cheng HWA, Lucy FE, Broaders MA, Mastitsky SE, Chen CH, Murray A. Municipal wastewater treatment plants as pathogen removal systems and as a contamination source of noroviruses and Enterococcus faecalis. J Water Health. 2012;10(3):380-9.

40. Alipour M, Hajiesmaili R, Talebjannat M, Yahyapour Y. Identification and antimicrobial resistance of Enterococcus Spp. isolated from the river and coastal waters in Northern Iran. Sci World J. 2014;2014.

41. Iweriebor BC, Obi LC, Okoh Al. Virulence and antimicrobial resistance factors of Enterococcus spp. isolated from fecal samples from piggery farms in Eastern Cape, South Africa. BMC Microbiol [Internet]. 2015;1-11. Available from: https://doi.org/10.1186/s12866-015-0468-7.

42. Fewtrell L, Bartram J. Water quality : guidelines, standards and health : assessment of risk and risk management for water-related infectious diseases. World Heal Organ IWA Publ [Internet]. 2001;1-431. Available from: https://apps.who.int/iris/handle/10665/42442.

43. Teklehaimanot GZ, Genthe B, Kamika I, Momba MNB. Prevalence of enteropathogenic bacteria in treated effluents and receiving water bodies and their potential health risks. Sci Total Environ. 2015 Jun;518:441-9.

44. Genthe B, Le Roux WJ, Schachtschneider K, Oberholster PJ, Aneck-Hahn NH, Chamier J. Health risk implications from simultaneous exposure to multiple environmental contaminants. Ecotoxicol Environ Saf [Internet]. 2013;93:1719. Available from:. https://doi.org/10.1016/j.ecoenv.2013.03.032.

45. Le Roux WJ. Microbial water quality in the upper Olifants River catchment: implications for health. African J Microbiol Res. 2012 Sep;6(36):6580-8.

46. Ye L, Zhang T. Pathogenic bacteria in sewage treatment plants as revealed by 454 pyrosequencing. Environ Sci Technol. 2011;45(17):7173-9.

47. Michalkiewicz M. Wastewater treatment plants as a source of bioaerosols. Polish J Environ Stud. 2019;28(4):2261-72.

48. Dehghani M, Sorooshian A, Ghorbani M, Fazlzadeh M, Miri M, Badiee P, et al. Seasonal variation in culturable bioaerosols in a wastewater treatment plant. Aerosol Air Qual Res. 2018;18(11):2826-39.

49. Forestier D, Lecornet É, Mosqueron L. LL. Exposure to bioaerosols for wastewater treatment plant workers: prioritization of the areas and tasks involving the greatest exposure, and prevention. Environnement, Risques et Sante. 2012;11(2):137-48.

50. Umgeni Water. Darvill wastewater works [internet]. Pietermaritzburg, South Africa; 2017. Available from: http://www.umgeni.co.za/projects/infrastructuremasterplans/docs/2017/vol2_section7.pdf.

51. Luther A, Abia K, Ubomba-jaswa E, Ndombo M, Momba B. Science of the Total Environment Impact of seasonal variation on Escherichia coli concentrations in the riverbed sediments in the Apies River, South Africa. Sci Total Environ [Internet]. 2015;537:462-9. Available from: https://doi.org/ 10.1016/.jscitotenv.2015.07.132

52. Janezic KJ, Ferry B, Hendricks EW, Janiga BA, Johnson T, Murphy S, et al. Phenotypic and genotypic characterization of Escherichia coli isolated from untreated surface waters. Open Microbiol J. 2013;7(1):9-19.

53. Ke D, Picard OISJ, Martineau F, Me C, Roy PH, Ouellette M, et al. Development of a PCR assay for rapid detection of enterococci. J Clin Microbiol. 1999:37(11):3497-503.

54. Jackson CR, Fedorka-Cray PJ, Barrett JB. Use of a genus- and species-specific multiplex PCR for identification of enterococci. J Clin Microbiol. 2004;42(8):3558-65.

55. Molechan C, Amoako DG, Luther A, Abia K, Somboro AM, Bester LA, et al. Science of the Total Environment Molecular epidemiology of antibioticresistant Enterococcus spp . from the farm-to-fork continuum in intensive poultry production in. Sci Total Environ [Internet]. 2019;692:868-78. Available from: https://doi.org/10.1016/j.scitotenv.2019.07.324.

56. Strachan N, Doyle M, Kasuga F, Rotariu O, Ogden I. Dose response modelling of Escherichia coli $\mathrm{O} 157$ incorporating data from foodborne and environmental outbreaks. Int J Food Microbiol. 2005;103(1):35-47.

\section{Publisher's Note}

Springer Nature remains neutral with regard to jurisdictional claims in published maps and institutional affiliations. 